\title{
The forelock sign: A new arthroscopic finding in partial subscapularis tears
}

\author{
Kakül işareti: Parsiyel subskapularis yırtıklarında yeni bir artroskopik bulgu
}

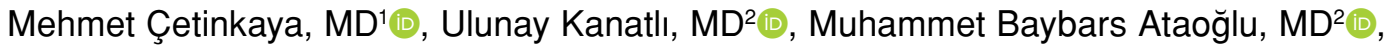

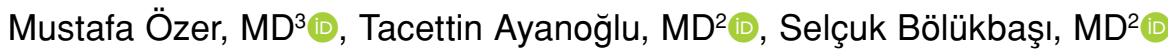 \\ 1Department of Orthopedics and Traumatology, Erzincan University Mengücek Gazi Training and Research Hospital, Erzincan, Turkey \\ ${ }^{2}$ Department of Orthopedics and Traumatology, Gazi University School of Medicine, Ankara, Turkey \\ ${ }^{3}$ Department of Orthopedics and Traumatology, Necmettin Erbakan University Meram Medical School, Konya, Turkey
}

\begin{abstract}
Objectives: This study aims to identify the forelock sign of partial tears of the subscapularis and to compare the incidences of this sign and air bag sign.

Patients and methods: One hundred and twenty patients (39 males, 81 females; mean age 51.3 years; range, 25 to 79 ) diagnosed as isolated subscapularis tear or isolated supraspinatus tear from among patients who underwent shoulder arthroscopy between January 2013 and January 2016 were divided into four groups of 30 patients each as the subscapularis tear (group 1), fullthickness supraspinatus tear (group 2), bursal-side supraspinatus tear (group 3), and articular-side supraspinatus tear (group 4) groups. All patients had video records of their operation. The integrity of the long head of biceps tendon (LHBT), Lafosse classification of the subscapularis tear, and the incidence of the forelock and air bag signs were evaluated.
\end{abstract}

Results: The incidence of the air bag sign in group 1 was $10 \%$ and that of the forelock sign was $60 \%$. The forelock sign was significantly more frequent in group 1 than in the other groups (odds ratio 10.46: 3.9-27.8 with 95\% confidence interval) and the air bag sign $(\mathrm{p}<0.001)$. The LHBT was mostly pathologic in this group, which was also statistically significant $(p<0.01)$. The incidence of the forelock sign in group 1 was similar in each LHBT pathology and Lafosse subgroups.

Conclusion: The forelock sign identified in this study was significantly frequent $(60 \%)$ in partial subscapularis tendon tears with strong inter- and intra-observer consistency while the air bag sign was rare $(10 \%)$. The LHBT disorders were strongly associated with subscapularis tears; however, the forelock sign was not an indicator of the condition of the LHBT and type of partial subscapularis tendon tear according to the Lafosse classification.

Keywords: Arthroscopy, rotator cuff tear, shoulder, subscapularis.
ÖZ

Amaç: Bu çalışmada, subskapularis parsiyel yırtıklarının kakül işareti tanımlandı ve bu işaret ile hava yastığı işaretinin insidansları karşılaştırıldı.

Hastalar ve yöntemler: Ocak 2013-Ocak 2016 tarihleri arasında omuz artroskopisi uygulanan hastalar arasından izole subskapularis yırtığ veya izole supraspinatus yırtığ tanısı konulan 120 hasta (39 erkek, 81 kadın; ort. yaş 51.3 yıl; dağılım, 25-79 yıl) subskapularis yırtığı (grup 1), tam kat supraspinatus yırtığı (grup 2), bursal yüz supraspinatus yırtığ 1 (grup 3) ve eklem yüzü supraspinatus yırtığ 1 (grup 4) grubu olmak üzere 30 'ar hastalık dört gruba ayrıldı. Tüm hastaların ameliyatının video kaydı vardı. Biseps tendonunun uzun başı (BTUB)'nın bütünlüğü, subskapularis yırtığının Lafosse sınıflandırması ve kakül ve hava yastığı işaretlerinin insidansı değerlendirildi.

Bulgular: Grup 1'de hava yastığı işaretinin insidansı $\% 10$, kakül işaretininki \%60 idi. Kakül işareti grup 1'de diğer gruplardan (olasılık oranı \%95 güven aralığında 10.46: 3.9-27.8) ve hava yastığı işaretinden anlamlı olarak daha sıktı $(\mathrm{p}<0.001)$. Biseps tendonunun uzun başı bu grupta çoğunlukla patolojikti ve bu da istatistiksel olarak anlamlıydı $(\mathrm{p}<0.01)$. Grup 1'de kakül işareti insidansı her BTUB patolojisinde ve Lafosse alt gruplarında benzerdi.

Sonuç: $\mathrm{Bu}$ çalışmada tanımlanan kakül işareti parsiyel subskapularis tendonu yırtıklarında güçlü gözlemciler arası ve gözlemciler içi tutarlılıkla anlamlı olarak sık (\%60) iken hava yastığ 1 işareti nadirdi (\%10). BTUB'nin bozuklukları subskapularis yırtıklarıyla güçlü bir şekilde ilişkiliydi fakat kakül işareti BTUB'nin durumunun veya Lafosse sınıflandırmasına göre parsiyel subskapularis tendon yırtığı tipinin bir göstergesi değildi. Anahtar sözcükler: Artroskopi, rotator manşet yırtı̆̆ı, omuz, subskapularis.

Received: June 10, 2019 Accepted: July 10, 2019 Published online: October 24, 2019

Correspondence: Mehmet Çetinkaya, MD. Erzincan Üniversitesi Mengücek Gazi Eğitim ve Araştırma Hastanesi Ortopedi ve Travmatoloji Kliniği, 24030 Erzincan, Turkey. Tel: +90 532 - 7969887 e-mail: drcetink@gmail.com 
Interest in subscapularis tears increases day by day. The studies of Gerber and Krushell ${ }^{[1]}$ and Lo and Burkhart ${ }^{[2]}$ were two giant leaps for understanding the clinical relevance of the subscapularis tendon repair which improves the outcomes after rotator cuff repair, and these are not the only ones providing data of improved outcomes following the surgical intervention for subscapularis tears. ${ }^{[3-6]}$

The recognition of partial subscapularis tears may be challenging because of the difficulty to acquire an appropriate angle of view and obscuring intra-articular structures like an inflamed biceps tendon with scuffing. Neyton et al. ${ }^{[7]}$ suggested an arthroscopic technique to view the subscapularis insertion site. However, it is necessary to place traction sutures to the subscapularis tendon through the subacromial space and then to re-evaluate the subscapularis insertion by intra-articular gazing under the traction of these sutures. Other than this, Sahu et al. ${ }^{[8]}$ reported an arthroscopic finding, named sentinel sign with a high inter- and intraobserver reliance which indicates scuffing, abrasion, or tear of the anterior part of the long head of biceps tendon (LHBT) that may show a subscapularis tendon rupture apparent or hidden on arthroscopy. Similarly, Wani et al. ${ }^{[9]}$ and Saremi ${ }^{[10]}$ reported the nodular scarring of a partially torn subscapularis tendon as an arthroscopic finding, which is named as air bag sign by Saremi. These efforts to reveal the hidden lesions of the subscapularis tears provided some advance in recognition of these lesions and drove scientists forward to make new investigations and find new viewpoints. In this study, we reported another arthroscopic finding named the forelock sign which is residual fringes of the superior glenohumeral ligament (SGHL) and coracohumeral ligament (CHL) lying down adjacent to the anterior aspect of the humeral head originating between the subscapularis tendon and LHBT. Our hypothesis was that the forelock sign would be more frequent in partial subscapularis tears than it was in fullthickness, partial articular-side, and partial bursalside supraspinatus tears and that the incidence of the forelock sign would be significantly higher than that of the air bag sign. Therefore, in this study, we aimed to identify the forelock sign of partial tears of the subscapularis and to compare the incidences of this sign and air bag sign.

\section{PATIENTS AND METHODS}

The prospectively collected surgery videos of 120 patients (39 males, 81 females; mean age 51.3 years; range, 25 to 79 ) diagnosed as isolated subscapularis tear or isolated supraspinatus tear and who underwent arthroscopic rotator cuff repair at the Gazi University School of Medicine by a senior surgeon between January 2013 to January 2016 were reviewed. Four groups were constituted with patients selected randomly by a randomization software. These groups including patients with each of the isolated rotator cuff pathologies were as follows: subscapularis tear (group 1), full-thickness supraspinatus tear (group 2), bursalside supraspinatus tear (group 3), and articular-side supraspinatus tear (group 4). The senior surgeon who performed the procedures was blinded to patients included in the study. The observers were not blinded to the diagnosis of the patients since they were allowed to watch the whole video. Being close to the SGHL-CHL complex was the reason why the supraspinatus tear types were chosen for comparison with subscapularis tears. The isolated term defined only the pathology regarding the rotator cuff, which means each patient might have additional shoulder pathologies such as superior labrum tear, subacromial impingement, acromioclavicular degenerative arthritis, or LHBT pathology. Only the accompanying LHBT pathologies were recorded. The videos with surgical repair of labrum pathologies for anterior or posterior instability were not included, since the forelock sign has only been observed in cases with rotator cuff tears. The massive rotator cuff pathologies were excluded to better reveal the each rotator cuff part's contribution to the constitution of the forelock sign. The intratendinous tears of the supraspinatus tendon were excluded. Patients having a history of prior surgery or severe trauma in the vicinity of involved shoulder (including fractures, dislocations, and falling from a height), traumatic subscapularis tears, osteoarthritis, and inflammatory joint diseases were also excluded. The study protocol was approved by the Erzincan Binali Yıldırım University Ethics Committee. A written informed consent was obtained from each patient. The study was conducted in accordance with the principles of the Declaration of Helsinki.

Forelock sign is the residual fringes of the SGHL and CHL lying down adjacent to the anterior aspect of the humeral head (Figure 1a-d). The reason for calling it as forelock is the resemblance of the humeral head to a face looking towards the glenoid fossa, and of the fibers of the SGHL and CHL to a piece of hair lying downwards (as in the horses) adjacent to the opposite side of this face, when the joint is viewed through the posterior portal of the shoulder. In some cases, SGHL and CHL were intact, therefore, there was no forelock sign (Figure 1e and f). Following the tear of the 

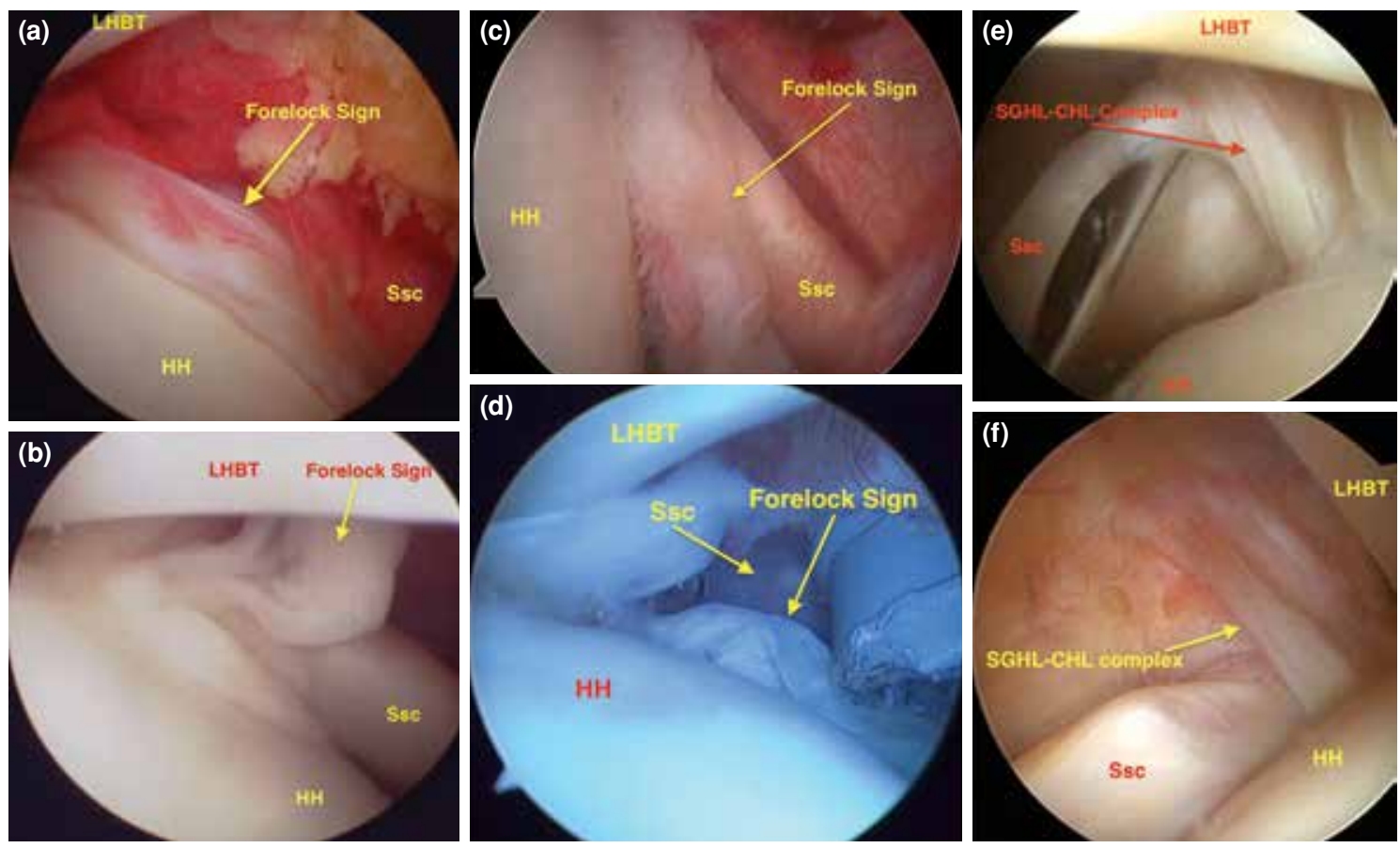

Figure 1. (a, b, c, d) Represent some presentation forms of forelock sign. (e, f) Represent sole partial subscapularis tendon tear without any forelock or sentinel signs.

HH: Humeral head; CHL: Coracohumeral ligament; LHBT: Long head of biceps tendon; SGHL: Superior glenohumeral ligament; Ssc: Superior-most tendon of subscapularis.

subscapularis tendon, the biceps tendon subluxates anteriorly, and the stabilizers of the biceps tendon including SGHL and CHL, which envelope the biceps tendon, begin fraying and lose their integrity. ${ }^{[11,12]}$ The fringes of these ligaments launch from the interval between the subscapularis tendon anteriorly and biceps tendon posteriorly, which conceal the partially torn subscapularis tendon near its insertion side. A hidden subscapularis tendon tear may be diagnosed following the debridement of these fibers by an arthroscopic shaver. Fraying of the LHBT (occurred secondary to tendinitis or degeneration) or a torn subscapularis tendon was not assumed as forelock sign (Figure 2). The fringes moving along with the biceps tendon when examining on arthroscopy are also not assumed as forelock sign. The videos were evaluated by two independent researchers of this study, except the senior surgeon who performed the procedures. The inter- and intra-observer correlations were calculated.

All of the procedures were performed in the same institute by the senior surgeon of this study and two assistants. General anesthesia, general anesthesia with interscalene brachial plexus block, and single interscalene block were the anesthesia options. The procedures were performed in semi- lateral position by rotating patients $20-30^{\circ}$ posteriorly to place the glenoid fossa parallel to the floor. ${ }^{[13]}$ The standard posterior portal was used for initial examination of the shoulders. Additional portals

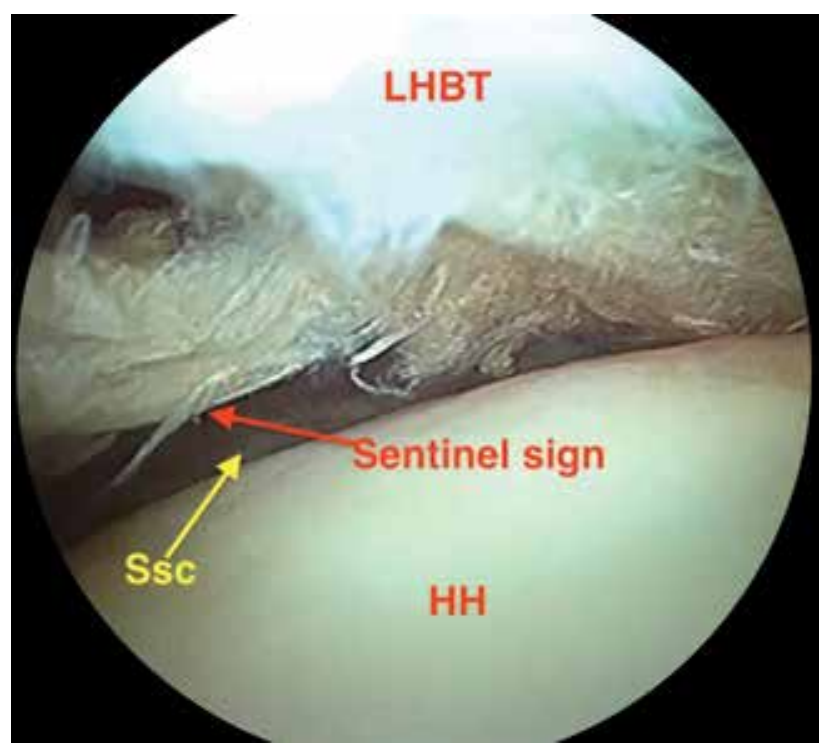

Figure 2. Scuffing of long head of biceps tendon, also known as sentinel sign.

LHBT: Long head of biceps tendon; HH: Humeral head; Ssc: Superior-most tendon of subscapularis. 


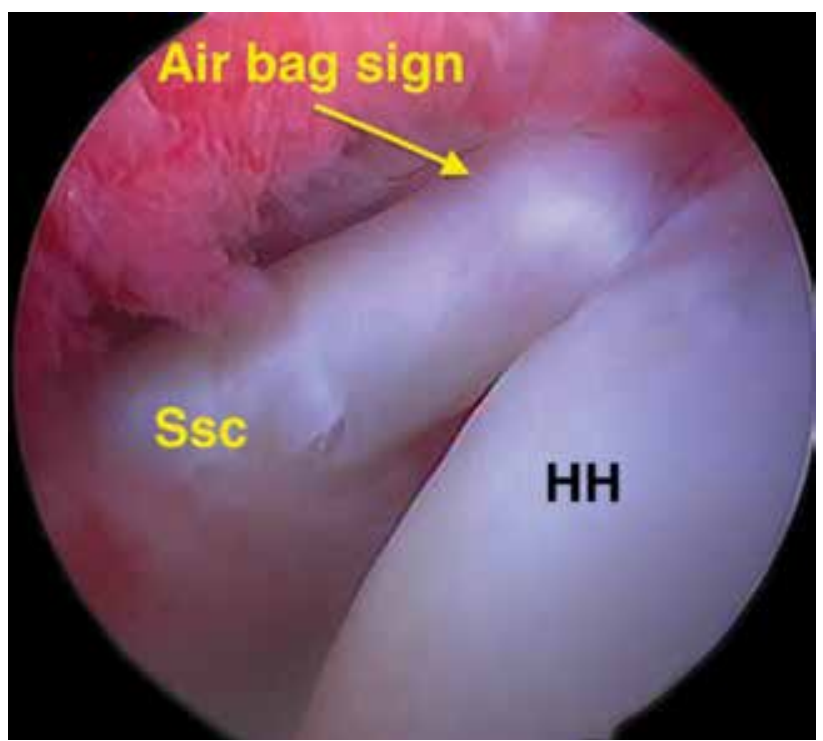

Figure 3. Nodular scarring of a partially torn subscapularis tendon, which is also known as air bag sign.

HH: Humeral head; LHBT: Long head of biceps tendon; Ssc: Superior-most tendon of subscapularis.

were constituted according to the pathology and planned arthroscopic intervention. The diagnoses of intra-articular pathologies were established with an arthroscopic probe. The tears of subscapularis tears were graded according to the Lafosse subscapularis tear classification system. ${ }^{[14]}$ Tears including upper ${ }^{1 / 3}$ and $2 / 3$ subscapularis tendon (Lafosse types 1,2 , and 3 ) were assumed as partial tears. The superior cuff tears were recorded as full-thickness tear, partial bursalside tear, and partial articular-side tear. Long head of biceps tendon pathologies were classified as healthy, tendinopathic (tendinitis or degenerated), dislocated, both dislocated and tendinopathic, and ruptured, as described previously. ${ }^{[15]}$ The subscapularis tears were also scrutinized in terms of intratendinous nodules which was first described by Wani et al..$^{[9]}$ in 2013 as nodules (Figure 3) arising from the intra-articular surface of a partially torn subscapularis tendon.

\section{Statistical analysis}

Power analysis tests were conducted to determine the number of control cases to be able to reject the null hypothesis that the failure rates for experimental and control subjects are equal with probability (power) 0.8 (1-type II error) and $\alpha=0.05$ (type I error). Dichotomous variables were assessed by crosstabs and Pearson's chi-square test. Normally distributing and homogenous numeric variables were assessed by analysis of variance and post hoc analysis. The interobserver agreement was measured by calculating the Kappa statistic. The intra-observer agreement was measured by calculating the inter-class coefficient (ICC). For all comparisons, statistical significance was reported at the value of $\mathrm{p}<0.05$ level (2-tailed). Statistical analyses were performed with the IBM SPSS version 21.0 software (IBM Corp., Armonk, NY, USA).

\section{RESULTS}

The power analysis tests revealed the number of patients needed to reject the null hypothesis that the failure rates are equal with probability (power) 0.8 [1-type II error ( $\beta)$ ] and $\alpha=0.05$ (type I error) as four in each control and study groups, when it was assumed that the rate of forelock sign was $50 \%$ in the study group and $10 \%$ in the control group. Nevertheless, the number of patients in each group was set to 30 to be able to apply parametric tests when evaluating normally distributing and homogenous numeric variables.

There were 292 full-thickness supraspinatus tears, 80 partial bursal-side supraspinatus tears, 36 articular-side supraspinatus tears, and 35 isolated subscapularis tears (totally 194 subscapularis tears) in 1,009 shoulder arthroscopy cases performed in the designated time period. Thirty randomly selected patients from each type of aforementioned tears were evaluated.

TABLE I

Mean age, gender, involved shoulder side, and dominant shoulder side of patients

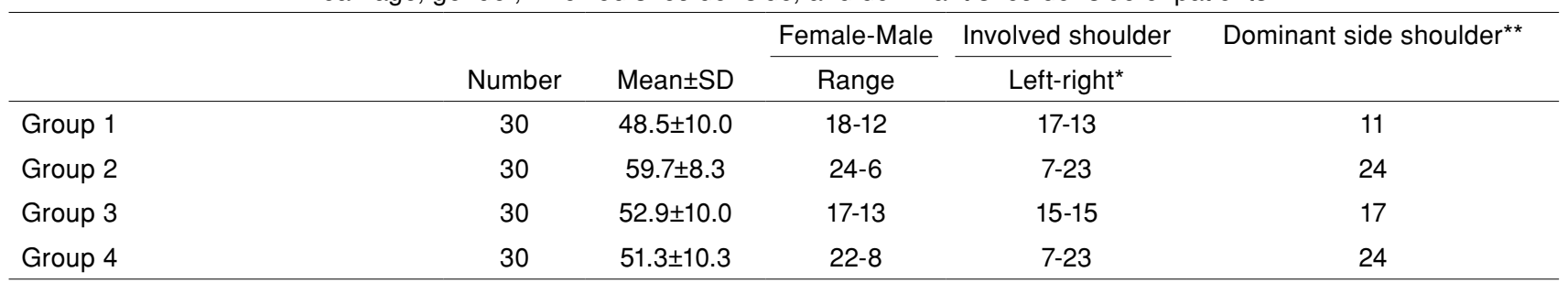

* and ${ }^{* *}$ describe a statistical significance of $p<0.01$. SD: Standard deviation. 
TABLE II

Incidence of forelock sign incidence in groups

\begin{tabular}{lccc}
\hline & Forelock sign (+) & Forelock sign (-) & $\begin{array}{c}\text { Odds ratio } \\
\text { (with Cl of 95\%) }\end{array}$ \\
\hline Group 1 & 18 & 12 & $10.46(3.9-27.8)$ \\
Group 2 & 2 & 28 & $0.19(0.04-0.8$ \\
Group 3 & 7 & 23 & $1.07(0.4-2.8)$ \\
Group 4 & 1 & 29 & $0.09(0.01-0.7)$ \\
\hline
\end{tabular}

Cl: Confidence interval.

The mean age, gender, and involved shoulder data are presented in Table I. Group 1 was the youngest group and group 2 was the oldest group. Group 4 was younger than group 3 . The difference was statistically significant $(\mathrm{p}<0.001)$. The involved shoulder side was mostly right in groups 2 and 4 while it was fifty-fifty in group 3 and mostly left in group $1(p<0.01)$. The gender distribution of the groups was statistically similar ( $\mathrm{p}>0.05)$.

The forelock sign was positive in $60 \%$ of isolated subscapularis tears (group 1). This rate differed from the other groups presented in Table II $(\mathrm{p}<0.001)$. The odds ratio (OR) of forelock sign for isolated subscapularis tears compared with other groups was calculated as 10.46 with $95 \%$ confidence interval (CI): 3.9-27.8. The incidence of the air bag sign was $10 \%$ in group 1 and was significantly less frequent than the forelock sign $(\mathrm{p}<0.001)$. As expected, there was no air bag sign of the subscapularis tendon in groups 2, 3, or 4 , and therefore, the OR of the air bag sign for the cohort of this study cannot be calculated. The LHBT was most commonly pathologic in group 1 followed by group $2(\mathrm{p}<0.01)$ (Table III). Although a statistical significance cannot be suggested due to the limited number of patients in the LHBT subgroups, the dislocation of the LHBT was always associated with subscapularis tears. The incidence of the forelock sign in group 1 was similar in each LHBT pathology and Lafosse subscapularis tear classification subgroups ( $p>0.05)$. There was no retracted isolated subscapularis tear (type 4 or 5) which may present with comma sign or sentinel sign defined previously by Burkhart et al. ${ }^{[16]}$ and Sahu et al. ${ }^{[8]}$ respectively. Although not included in this study, there was

TABLE III

Long head of biceps tendon pathology types of groups

\begin{tabular}{lcccccc}
\hline & $\begin{array}{c}\text { Healthy } \\
\text { LHBT }\end{array}$ & $\begin{array}{c}\text { Tendinitis- } \\
\text { degeneration }\end{array}$ & Dislocation & Rupture & $\begin{array}{c}\text { Dislocation and } \\
\text { tendinitis-degeneration }\end{array}$ & $\begin{array}{c}\text { Total number of } \\
\text { LHBT pathologies }\end{array}$ \\
\hline Group 1 & 13 & 10 & 1 & 2 & 4 & 17 \\
Group 2) & 15 & 14 & - & 1 & - & 15 \\
Group 3 & 25 & 5 & - & - & - & 5 \\
Group 4 & 21 & 9 & - & - & - & 9 \\
\hline
\end{tabular}

LHBT: Long head of biceps tendon.

TABLE IV

Lafosse type distribution of subscapularis tears

\begin{tabular}{cccccc}
\hline & \multicolumn{2}{c}{ Number (Percentage) } & & \multicolumn{2}{c}{ Forelock (Percentage) } \\
\cline { 2 - 3 } \cline { 5 - 6 } Lafosse type & $\mathrm{n}$ & $\%$ & & $\mathrm{n}$ & $\%$ \\
\hline 1 & 7 & 23.3 & & 4 & 57.1 \\
2 & 13 & 43.3 & & 8 & 61.5 \\
3 & 10 & 33.3 & & 6 & 60 \\
4 & - & & & \\
5 & - & & & \\
\hline
\end{tabular}


no forelock sign recorded in the retracted tears of subscapularis tendon in our patient database. Table IV demonstrates the frequency of forelock sign in each subscapularis tear type classified according to the Lafosse system.

The Kappa value and ICC were calculated to be 0.861 and 0.865 , respectively, which revealed strong inter- and intra-observer agreement levels.

There were only three cases with subscapularis nodules, and they were all intratendinous type tears. There was no other intratendinous subscapularis tear in this group. Two of them also had positive forelock sign.

\section{DISCUSSION}

The most important outcome of the current study was the rate of positive forelock sign in the subscapularis tear group (group 1) as 60\% (OR: 10.46 with 95\% CI: 3.9-27.8), which was significantly higher than the other groups. ${ }^{[17]}$ Inter- and intra-observer agreement levels were excellent indicating strong consistency and reproducibility. It revealed similar incidence rates among LHBT pathology types and Lafosse subscapularis tear classification subgroups.

The mean age of the patients in group 1 was younger than the others. This could be due to the later onset of superior rotator cuff pathologies secondary to subacromial impingement or different anatomical variations causing a rotator cuff tear while subcoracoid impingement is still a debated issue. ${ }^{[18,19]}$ Eventually, the etiologic factors causing a rotator cuff tear seems to be making it quicker in subscapularis tears than in supraspinatus tears. The increase in the mean age was not assumed to be a contributing factor for the forelock sign because despite the younger mean age, subscapularis tears revealed higher rate of SGHL-CHL injury and forelock sign positivity.

The involved shoulder was mostly left and nondominant side. This was not concordant with the literature. ${ }^{[20]}$ In this study, there was no data to interpret and explain this finding.

Long head of biceps tendon curves sharply in the inter-tubercular groove through the intra-articular space to attach to the supraglenoid tubercle, thus tends to dislocate anteromedially. What retain the LHBT in the groove are soft tissue structures rather than bony tunnel. ${ }^{[21]}$ The close relationship among the insertion of the superior-most tendon of the subscapularis, CHL, and SGHL was pointed out previously by Walch et al. ${ }^{[22]}$ The contribution of the subscapularis insertion as a stabilizer of the LHBT in the inter-tubercular groove was previously demonstrated by a number of studies and recently reported by Arai et al. ${ }^{[23]}$ It inserts to the upper margin of the lesser tuberosity and supports the LHBT anteriorly and inferiorly. ${ }^{[24]}$ The dislocated type LHBT pathologies in this study (five patients) were all included in the subscapularis tear group. The SGHL inserts to fovea capitis of the humeral head and has three types of origin: (i) the middle glenohumeral ligament, LHBT, and superior labrum; (ii) LHBT and superior labrum; and (iii) the LHBT only. ${ }^{[25]}$ The CHL originates from the lateral aspect of the coracoid process and inserts mainly lateral rotator interval. ${ }^{[23]}$ The SGHL, CHL, and superior-most tendon of the subscapularis play a critical role for the stabilization of the LHBT. The SGHL and CHL fibrils converge and intricate at the lateral interval and act as a pulley system for the LHBT while the subscapularis supports it anteromedially. ${ }^{[22,26]}$ According to Arai et al. ${ }^{[23]}$ and also in our opinion, the main structure stabilizing the LHBT in the groove at the lateral rotator interval is the superior-most tendon of the subscapularis, and SGHL and CHL are the minor supporters which act as a pulley to provide fine-tuning for the course of the LHBT. The SGHL and CHL alone are not sufficient enough to stabilize the LHBT without subscapularis. Therefore, they detach from their insertion or origin when the integrity of the subscapularis tendon is deteriorated because of the insufficiency in stabilizing the LHBT by themselves. ${ }^{[23]}$ We believe that is why the forelock sign develops following a subscapularis tendon tear. The reason for partial subscapularis tears without any forelock sign cannot be determined with this study, but it might be due to the resorption of the SGHL-CHL fibers in time.

The LHBT was more frequently pathologic in the isolated subscapularis and full-thickness supraspinatus tear groups (groups 1 and 2) than the isolated bursal-side and articular-side tear groups (groups 3 and 4). Therefore, the LHBT alone is not a predictive finding for subscapularis tears. However, the dislocated LHBTs (five cases) were only present in the subscapularis tear group, which makes LHBT dislocation seeming specific to subscapularis tears. Nevertheless, the forelock sign was present in 18 of the subscapularis tears while it was present in only two of full-thickness supraspinatus tears.

Previously, Sahu et al. ${ }^{[8]}$ have described sentinel sign indicating scuffing, abrasion, or tear of the anterior part of LHBT that may indicate a subscapularis tendon rupture apparent or hidden on arthroscopy. Long head of biceps tendon stability is provided mainly by the most superior tendon of the subscapularis. Following the deterioration 
of this structure, LHBT subluxation develops, and the sentinel sign arises. This sign is similar with the forelock sign described in the current study. However, the fringes are originated from biceps tendon in sentinel sign while those are originated from SGHL-CHL complex in forelock sign. The fringes that the authors observed on arthroscopy in their study could also be arising from SGHL-CHL complex since whether the fringes at the anterior side of the biceps tendon move along with the biceps tendon during the biceps stability examination by pulling it into the joint with an arthroscopic probe was undetermined by the authors. Besides, they did not specify through which portal the sentinel sign was observed. The figures in their paper look like as if the sign was evaluated through anterior portal or trough a $70^{\circ}$ arthroscope. For the forelock sign described by the current study, there was no need to change the viewing portal or the arthroscope during the arthroscopic examination. On the other hand, when the biceps tendon of the patient is ruptured, the sentinel sign can no longer exist in subscapularis tears. However, the forelock sign can still be present in those cases because of being unrelated to biceps tendon. Moreover, the biceps tendon degeneration and scuffing could be irrelevant to subscapularis tendon pathology and may arise from another intraarticular disorder. ${ }^{[27]}$

Another arthroscopic sign indicating a partial subscapularis tear described in the literature is the nodular formation in the substance of the torn tendon. The incidence of this lesion in the current study was $10 \%$ (three of 30 patients) in the subscapularis tear group, which was very rare when compared to the forelock sign. Furthermore, this sign was only positive in intratendinous subscapularis tears, and the number of intratendinous tears was three. The forelock sign was positive in two of them. The nodular formation was first described by Wani et al. ${ }^{[9]}$ as the healing with nodular scar tissue of a partially torn subscapularis tendon. Subsequently in 2016, Saremi described the air bag sign which was posteriorly bulging of the partially torn subscapularis tendon and added that this lesion was only seen in interstitial tears and in the internally rotated arms during the arthroscopy. ${ }^{[10]}$ These two lesion types described in two different articles were actually same lesions in our opinion and were comparable with the forelock sign. However, they were not so frequent as the forelock sign in partial subscapularis tears.

This study has some limitations. The thought that the fibrils constituting the forelock sign belong to the SGHL-CHL complex has not been proved by histopathological assessment. However, the origin of the fibers constituting this sign is not within the scope of this study. The forelock sign describes the fibers lying downwards adjacent to the anterior side of the humeral head. Another important limitation was that there was no true control group. Therefore, whether this sign occurs in patients without rotator cuff tears is still unknown.

In conclusion, the forelock sign identified in the current study was found to be significantly frequent in the partial subscapularis tendon tears with strong inter- and intra-observer consistency while the nodules were not. This sign can be a very useful finding in shoulder arthroscopies for surgeons to diagnose the hidden partial subscapularis tears. The LHBT disorders, particularly the dislocations, are also strongly associated with subscapularis tears, and the forelock sign was irrelevant with the condition of the LHBT and the type of partial subscapularis tendon tear according to the Lafosse classification.

\section{Declaration of conflicting interests}

The authors declared no conflicts of interest with respect to the authorship and/or publication of this article.

\section{Funding}

The authors received no financial support for the research and/or authorship of this article.

\section{REFERENCES}

1. Gerber C, Krushell RJ. Isolated rupture of the tendon of the subscapularis muscle. Clinical features in 16 cases. J Bone Joint Surg [Br] 1991;73:389-94.

2. Lo IAN, Burkhart S. Subscapularis Tears: Arthroscopic Repair of the Forgotten Rotator Cuff Tendon. Tech Shoulder Elbow Surg 2002;3:282-91.

3. Lanz U, Fullick R, Bongiorno V, Saintmard B, Campens C, Lafosse L. Arthroscopic repair of large subscapularis tendon tears: 2- to 4-year clinical and radiographic outcomes. Arthroscopy 2013;29:1471-8.

4. Grueninger P, Nikolic N, Schneider J, Lattmann T, Platz A, Chmiel C, et al. Arthroscopic Repair of Massive Cuff Tears With Large Subscapularis Tendon Ruptures (Lafosse III/ IV): A Prospective Magnetic Resonance Imaging-Controlled Case Series of 26 Cases With a Minimum Follow-up of 1 Year. Arthroscopy 2015;31:2173-82.

5. Seppel G, Plath JE, Völk C, Seiberl W, Buchmann S, Waldt $S$, et al. Long-term results after arthroscopic repair of isolated subscapularis tears. Am J Sports Med 2017;45:759-66.

6. Saltzman BM, Collins MJ, Leroux T, Arns TA, Griffin JW, Romeo AA, et al. Arthroscopic repair of isolated subscapularis tears: a systematic review of techniquespecific outcomes. Arthroscopy 2017;33:849-60.

7. Neyton L, Daggett M, Kruse K, Walch G. The Hidden lesion of the subscapularis: arthroscopically revisited. Arthrosc Tech 2016;5:877-81. 
8. Sahu D, Fullick R, Giannakos A, Lafosse L. Sentinel sign: a sign of biceps tendon which indicates the presence of subscapularis tendon rupture. Knee Surg Sports Traumatol Arthrosc 2016;24:3745-9.

9. Wani Z, Mangattil R, Butterfield T, Hildebrand K, Kamineni S. Subscapularis partial tear nodule causing shoulder rotational triggering. Knee Surg Sports Traumatol Arthrosc 2015;23:573-6.

10. Saremi H. Interstitial tear of the subscapularis tendon, arthroscopic findings and technique of repair. Arch Bone Jt Surg 2016;4:177-80.

11. Bey MJ, Elders GJ, Huston LJ, Kuhn JE, Blasier RB, Soslowsky LJ. The mechanism of creation of superior labrum, anterior, and posterior lesions in a dynamic biomechanical model of the shoulder: the role of inferior subluxation. J Shoulder Elbow Surg 1998;7:397-401.

12. Chen $\mathrm{CH}$, Chen $\mathrm{CH}$, Chang $\mathrm{CH}$, Su CI, Wang $\mathrm{KC}$, Wang IC, et al. Classification and analysis of pathology of the long head of the biceps tendon in complete rotator cuff tears. Chang Gung Med J 2012;35:263-70.

13. Cetinkaya M, Pozisyonlar. In: Kanatli U, editor. Yeni başlayanlar için omuz artroskopisi. Ankara: Azim Matbaacilık; 2015. s. 113-6.

14. Lafosse L, Jost B, Reiland Y, Audebert S, Toussaint B, Gobezie R. Structural integrity and clinical outcomes after arthroscopic repair of isolated subscapularis tears. J Bone Joint Surg [Am] 2007;89:1184-93.

15. Ataoglu MB, Cetinkaya M, Ozer M, Ayanoglu T, Kanatli $\mathrm{U}$. The high frequency of superior labrum, biceps tendon, and superior rotator cuff pathologies in patients with subscapularis tears: A cohort study. J Orthop Sci 2018;23:304-9.

16. Burkhart SS, Tehrany AM. Arthroscopic subscapularis tendon repair: Technique and preliminary results. Arthroscopy 2002;18:454-63.

17. Atik OŞ. Which articles do we prefer to publish? Eklem Hastalik Cerrahisi 2018;29:1.
18. Özer M, Ataoğlu MB, Çetinkaya M, Ayanoğlu T, Kaptan AY, Kanatlı U. Do intra-articular pathologies accompanying symptomatic acromioclavicular joint degeneration vary across age groups? Eklem Hastalik Cerrahisi 2019;30:2-9.

19. Kanatli U, Ayanoğlu T, Aktaş E, Ataoğlu MB, Özer M, Çetinkaya M. Grade of coracoacromial ligament degeneration as a predictive factor for impingement syndrome and type of partial rotator cuff tear. J Shoulder Elbow Surg 2016;25:1824-8.

20. Edwards TB, Walch G, Nové-Josserand L, Boulahia A, Neyton L, O'Connor DP, et al. Arthroscopic debridement in the treatment of patients with isolated tears of the subscapularis. Arthroscopy 2006;22:941-6.

21. Clark JM, Harryman DT 2nd. Tendons, ligaments, and capsule of the rotator cuff. Gross and microscopic anatomy. J Bone Joint Surg [Am] 1992;74:713-25.

22. Walch G, Nove-Josserand L, Levigne C, Renaud E. Tears of the supraspinatus tendon associated with "hidden" lesions of the rotator interval. J Shoulder Elbow Surg 1994;3:353-60.

23. Arai R, Mochizuki T, Yamaguchi K, Sugaya H, Kobayashi M, Nakamura T, et al. Functional anatomy of the superior glenohumeral and coracohumeral ligaments and the subscapularis tendon in view of stabilization of the long head of the biceps tendon. J Shoulder Elbow Surg 2010;19:58-64.

24. Arai R, Sugaya H, Mochizuki T, Nimura A, Moriishi J, Akita K. Subscapularis tendon tear: an anatomic and clinical investigation. Arthroscopy 2008;24:997-1004.

25. DePalma AF. Surgery of the shoulder. 3rd ed. Philadelphia: J.B. Lippincott; 1973.

26. Neer CS 2nd, Satterlee CC, Dalsey RM, Flatow EL. The anatomy and potential effects of contracture of the coracohumeral ligament. Clin Orthop Relat Res 1992;280:182-5.

27. Wu YT, Su WR, Wu PT, Shen PC, Jou IM. Degradation of elastic fiber and elevated elastase expression in long head of biceps tendinopathy. J Orthop Res 2017;35:1919-26. 